Review

\title{
Biomarkers in the Diagnosis, Management, and Prognostication of Perioperative Right Ventricular Failure in Cardiac Surgery-Are We There Yet?
}

\author{
Habib Jabagi ${ }^{1}$ D, Lisa M. Mielniczuk ${ }^{2}$, Peter P. Liu ${ }^{2}$, Marc Ruel $^{1}$ and Louise Y. Sun ${ }^{3,4, *(D)}$ \\ 1 Divisions of Cardiac Surgery, University of Ottawa Heart Institute, Ottawa, ON K1Y 4W7, Canada; \\ hjabagi@ottawaheart.ca (H.J.); mruel@ottawaheart.ca (M.R.) \\ 2 Cardiology, University of Ottawa Heart Institute, Ottawa, ON K1Y 4W7, Canada; \\ LMielniczuk@ottawaheart.ca (L.M.M.); pliu@ottawaheart.ca (P.P.L.) \\ 3 Cardiac Anesthesiology, University of Ottawa Heart Institute, Ottawa, ON K1Y 4W7, Canada \\ 4 School of Epidemiology and Public Health, University of Ottawa, Ottawa, ON K1G 5Z3, Canada \\ * Correspondence: lsun@ottawaheart.ca; Tel.: +1-613-696-7382
}

Received: 23 February 2019; Accepted: 22 April 2019; Published: 25 April 2019

\begin{abstract}
Right ventricular failure (RVF) is a major risk factor for end organ morbidity and mortality following cardiac surgery. Perioperative RVF is difficult to predict and detect, and to date, no convenient, accurate, or reproducible measure of right ventricular (RV) function is available. Few studies have examined the use of biomarkers in RVF, and even fewer have examined their utility in the perioperative setting of patients undergoing cardiac surgery. Of the available classes of biomarkers, this review focuses on biomarkers of (1) inflammation and (2) myocyte injury/stress, due to their superior potential in perioperative RV assessment, including Galectin 3, ST2/sST2, CRP, cTN/hs-cTn, and BNP/NT-proBNP. This review was performed to help highlight the importance of perioperative RV function in patients undergoing cardiac surgery, to review the current modalities of RV assessment, and to provide a review of RV specific biomarkers and their potential utilization in the clinical and perioperative setting in cardiac surgery. Based on current evidence, we suggest the potential utility of ST2, sST2, Gal-3, CRP, hs-cTn, and NT-proBNP in predicting and detecting RVF in cardiac surgery patients, as they encompass the multifaceted nature of perioperative RVF and warrant further investigation to establish their clinical utility.
\end{abstract}

Keywords: right ventricular failure; biomarkers; cardiac surgery; natriuretic peptides; Galectin-3; ST2; sST2

\section{Introduction}

Acute right ventricular failure (RVF) is a major risk factor for end organ morbidity and mortality following cardiac surgery. It is associated with difficult separation from cardiopulmonary bypass (CPB), renal and hepatic dysfunction, an up to $75 \%$ increase in in-hospital mortality, and poor late survival [1,2]. RVF is present in almost $50 \%$ of patients with postoperative hemodynamic instability [3] and is especially relevant in those who undergo surgery for congenital heart disease, mitral valve disease complicated by pulmonary hypertension (PH), coronary artery disease (CAD), orthotopic heart transplantation, and left ventricular (LV) assist device (LVAD) implantation. RVF is difficult to predict and diagnose in the perioperative setting [4]. This in turn may result in missed opportunities for optimization, prevention, and early treatment. Our review focuses on a novel aspect of RVF prediction, detection, and prognostication using biomarkers. We will begin with a brief review of the pathophysiology of perioperative RVF and traditional perioperative right ventricular (RV) assessment modalities, followed by the potential role of biomarkers in the perioperative assessment of RV function, 
risk stratification, and prognostication. Although biomarkers have yet to be established as clinical tools in the perioperative assessment of RV function, the current manuscript highlights their potential based on current evidence and provides recommendations for future research.

\section{The Importance of RV Function Post Cardiac Surgery}

Perioperative RVF is deadly. In a study of 52 patients requiring inotropic support following cardiac surgery, severe, isolated LV failure was associated with $33 \%(n=3 / 10)$ in-hospital mortality, while severe, isolated RVF was associated with $90 \%(n=9 / 10)$ mortality, and those with biventricular failure were associated with an $82 \%(n=9 / 11)$ mortality rate, highlighting the importance of RV function [5]. In fact, RV dysfunction is an independent predictor of major adverse cardiac events such as cardiac death and HF hospitalization [6], and the addition of RV function improved risk stratification in those undergoing surgeries for $\mathrm{CAD}$, congenital heart disease, and end stage HF [1]. Furthermore, in patients undergoing surgery for acute pulmonary embolism (PE), acute RVF is associated with higher rates of intraoperative cardiopulmonary resuscitation and mortality, as well as mortality at 30 days $[7,8]$. Despite its prevalence and prognostic importance, perioperative RVF remains poorly understood and investigated [4]. Existing RV studies are often limited by their retrospective design and small prospective sample sizes, as randomization is difficult due to its multi-faceted etiology [1]. The absence of best practice guidelines on the diagnosis and treatment of perioperative RVF is also concerning.

\section{Etiology and Definition}

The most common cause of acute RVF is LV failure. Other common perioperative etiologies are summarized in Table 1. RVF is defined physiologically as an inability of the RV to provide adequate blood flow through the pulmonary circulation at normal right atrial pressure (RAP) [9] and clinically by the presence of hypotension, an RAP $>15 \mathrm{mmHg}$, and clear lungs [2]. Additional diagnostic criteria including pulmonary artery pressure and cardiac index have been used perioperatively [10]. However, these measures are confounded by the presence of LV systolic or diastolic dysfunction, raised intrathoracic pressure in mechanically ventilated patients, pre-existing $\mathrm{PH}$, and tricuspid regurgitation [2]. To date, a widely applied definition of perioperative RVF is only available in the context of LVAD implantation, as postoperative need for inotropic and/or vasodilator support for $\geq 14$ days, a right ventricular assist device (RVAD), or inhaled nitric oxide for $>48 \mathrm{~h}$ [11]. Recently, a three-item criteria was proposed in non-LVAD patients, as (1) hemodynamic instability, defined as difficult or complex separation from CPB, (2) $>20 \%$ reduction in RV fraction area change as measured by two-dimensional echocardiography, and (3) anatomical visualization of impaired or absent RV wall motion, by direct intraoperative visual inspection [12].

Table 1. Common causes of right ventricular failure (RVF) post cardiac surgery.

\begin{tabular}{cc}
\hline Mechanism & Etiologies \\
\hline Intrinsic RV failure (normal afterload) & Ischemia/infarction \\
& Coronary embolism (air or thrombus) \\
Occlusive CAD & Bypass graft dysfunction/thrombosis \\
Postoperative RV dysfunction \\
Suboptimal myocardial protection intraoperatively \\
Inflammatory CPB effects (long CPB times) \\
Arrhythmias (AVNRT or loss of AV synchrony) \\
Cardiotomy
\end{tabular}


Table 1. Cont.

\begin{tabular}{cc}
\hline Mechanism & Etiologies \\
\hline RV failure secondary to increased afterload & LVF \\
MVD with PH & Protamine induced PH \\
Ischemia-reperfusion injury & PE \\
RV failure secondary to increased volume overload & ARDS \\
& Pre-existing PH or OSA \\
\hline & Excessive blood transfusions \\
& Excessive fluid administration \\
Cardiac anatomical abnormalities & Severe TR or PR \\
\hline & CHD \\
& ASD \\
& VSD \\
Miscellaneous & OHT \\
& PH \\
& Prolonged donor ischemic time \\
& Obstruction of PA anastomotic site \\
& Acute rejection \\
LVAD
\end{tabular}

Abbreviations: RV-right ventricular; CAD—coronary artery disease; CHD—congenital heart disease; CPB — cardiopulmonary bypass; AVNRT—atrioventricular nodal re-entrant tachycardia; AV—atrioventricular; $\mathrm{PH}$ - pulmonary hypertension; RVOT—right ventricular outflow obstruction; OHT—orthotopic heart transplant; LVAD—left ventricular assist device; LVF-left ventricular failure; MVD- mitral valve disease; OSA—obstructive sleep apnea; PA—pulmonary artery; PR—pulmonary regurgitation; TR — tricuspid regurgitation; ASD—atrial septal defect; VSD—ventricular septal defect; ARDS—acute respiratory distress syndrome; PE—pulmonary embolism.

\section{Traditional Approaches to Measuring RV Function}

Perioperative assessment of RV function is complicated by a relative lack of practical and reproducible modalities in this setting [13] as well as the interplay between intrinsic biventricular myocardial performance and dynamic RV loading conditions [14]. Due to relative under-investigation of RV function compared to the LV [4,5,14], practical and reproducible means of measurement do not exist [13]. Table 2 summarizes common perioperative RV assessment approaches, their indications, advantages, and disadvantages.

Cardiac magnetic resonance imaging (MRI) is regarded as the current gold standard for non-invasive RV assessment [15], and right heart catheterization using pulmonary artery catheters is the invasive gold standard [13,16]. Widespread use of cardiac MRI is limited by its higher cost, longer procedural time, and the impracticality of MRI-specific safety precautions in mechanically ventilated patients and those with metal implants or temporary pacing wires. The routine use of pulmonary artery catheters is dwindling in many centers, in favor of less invasive methods such as central venous pressure (CVP). However, CVP measurements are influenced by mechanical ventilation, respiratory pathology, and changes in preload [17].

Echocardiography is readily available and frequently used perioperatively to assess RV function. The acquisition of perioperative transthoracic images (TTE) is challenged by the presence of positive pressure ventilation, chest tubes, bandages, and the fact that established quantitative measures of RV function are only validated in TTEs of spontaneously breathing patients [18]. Meanwhile, the widely used two-dimensional transesophageal echocardiography (TEE) is limited by the RV's complex geometry [19]. Additional limitations of echocardiography are its subjectivity to inter- and intra-observer variability [20] and the fact that visual estimates of RV function often do not correlate well with the actual degree of venous congestion and end organ function. 
Table 2. Current perioperative right ventricular (RV) assessment modalities.

\begin{tabular}{|c|c|c|c|c|}
\hline Diagnostic Tool & Indication & Information Provided & $\begin{array}{l}\text { Current Perioperative Use in } \\
\text { Cardiac Surgery }\end{array}$ & $\begin{array}{l}\text { Role in Perioperative Risk Stratification of } \\
\text { RVF in Cardiac Surgery Patients }\end{array}$ \\
\hline Cardiac MRI & $\begin{array}{ll}\text { - } & \text { Cardiomyopathies } \\
\text { - } & \text { Myocarditis } \\
\text { - } & \text { Hemochromatosis patients } \\
\text { - } & \text { Congenital heart diseases } \\
& \text { Conary artery disease }\end{array}$ & $\begin{array}{l}\text { - Gold standard for quantitative } \\
\text { noninvasive measurement of RV } \\
\text { volume, mass and ejection } \\
\text { fraction [21] } \\
\text { - Myocardial ischemia and } \\
\text { viability (delayed gadolinium } \\
\text { enhancement of } \\
\text { fibrotic/scarred myocardium) } \\
\text { - } \quad \text { General structure and function }\end{array}$ & $\begin{array}{l}\text { - Surgical planning in complex } \\
\text { congenital cases } \\
\text { - } \quad \begin{array}{l}\text { Pre-CABG to determine } \\
\text { revascularization strategy }\end{array}\end{array}$ & $\begin{array}{l}\text { - } \quad \text { Not feasible: } \\
\text { - } \quad \text { Expensive } \\
\text { - } \quad \text { Pime consuming } \\
\text { especially in ventilated and/or } \\
\text { ICU patients } \\
\text { - Repeat scans for continuous RVF } \\
\text { assessment impossible }\end{array}$ \\
\hline RHC & $\begin{array}{ll}\text { - } & \text { Identify or exclude HF } \\
\text { - } & \text { Shock (differentiate cardiac } \\
\text { - } & \text { vs. non-cardiac) } \\
\text { - } & \text { Congenital heart disease } \\
\text { - } & \text { PH (differentiate primary } \\
& \text { vs. secondary) } \\
\text { - } & \text { Heart transplant }\end{array}$ & $\begin{array}{ll}\text { - } & \text { Gold standard for invasive } \\
\text { - } & \text { assessment of the RV } \\
\text { - } & \text { Chamber pressures } \\
\text { - } & \text { Pulmonary artery pressure } \\
\text { - } & \text { Ejection fraction } \\
\text { - } & \text { Vascular resistances }\end{array}$ & 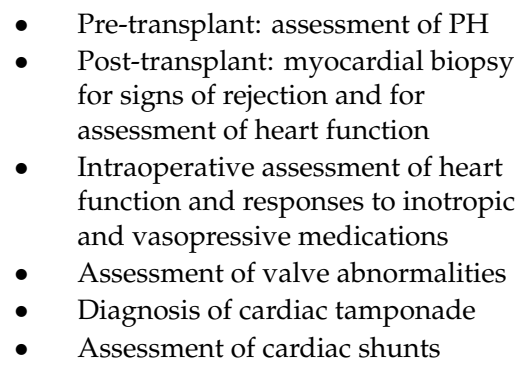 & $\begin{array}{l}\text { - } \quad \text { High diagnostic yield: } \\
\text { - } \quad \text { Helinuous monitoring of RV function } \\
\text { - } \quad \text { Provides information on responses of the } \\
\text { - } \quad \text { No to treatment } \\
\text { surgical patients }\end{array}$ \\
\hline Chest X-ray & $\begin{array}{ll}\text { - } & \text { Pulmonary assessment } \\
\text { - } & \text { Fluid overload }\end{array}$ & $\begin{array}{l}\text { - RV enlargement (globular } \\
\text { appearance of the cardiac } \\
\text { silhouette and loss of the } \\
\text { retrosternal airspace on lateral } \\
\text { films) [21] } \\
\text { - Enlarged main PA in patients } \\
\text { with PH [22] }\end{array}$ & $\begin{array}{l}\text { - } \quad \text { Routinely done as part of } \\
\text { preoperative assessment }\end{array}$ & - Low diagnostic yield \\
\hline RAP (or CVP) & $\begin{array}{l}\text { - All patients undergoing } \\
\text { cardiac surgery with a } \\
\text { central line in place }\end{array}$ & $\begin{array}{ll}\text { - } & \text { Volume status } \\
\text { - } & \text { Indirect measure of RV function }\end{array}$ & $\begin{array}{ll}\text { - } & \text { Routinely placed in all cardiac } \\
\text { surgery patients } \\
\text { - } \\
\text { RV prognostication in patients } \\
\text { with LVAD }\end{array}$ & $\begin{array}{ll}- & \text { Medium diagnostic yield: } \\
- & \text { Indirect measure of RV function } \\
- & \text { RAP }>15 \mathrm{mmHg} \text { (RVF after LVAD) [23] } \\
- & \text { RAP:PCWP }>0.63 \text { (RVF after LVAD) [24] } \\
- & \text { RAP:PCWP > 0.86 (RVF after acute } \\
& \text { MI) [25] } \\
\text { - } & \text { PVR }>3.6 \mathrm{WU} \text { (RVF after LVAD) [26] }\end{array}$ \\
\hline
\end{tabular}


Table 2. Cont.

\begin{tabular}{|c|c|c|c|c|}
\hline Diagnostic Tool & Indication & Information Provided & $\begin{array}{l}\text { Current Perioperative Use in } \\
\text { Cardiac Surgery }\end{array}$ & $\begin{array}{l}\text { Role in Perioperative Risk Stratification of } \\
\text { RVF in Cardiac Surgery Patients }\end{array}$ \\
\hline $\mathrm{ECHO}$ & $\begin{array}{ll}\text { - } & \text { Heart failure } \\
\text { - } & \text { CHD } \\
\text { - } & \text { PAH } \\
\text { - } & \text { Infectivular disease } \\
\text { - } & \text { Pericarditis } \\
\text { - } & \text { Tamponade }\end{array}$ & $\begin{array}{l}\text { - General structure and function } \\
\text { - } \quad \text { Ejection fraction } \\
\text { - } \quad \text { Valve function and defects } \\
\text { Cardiac output }\end{array}$ & $\begin{array}{l}\text { - } \quad \text { Case dependent } \\
\text { - } \\
\text { Assessment of valve } \\
\text { repair/replacement } \\
\text { - } \\
\text { Failure to wean patient from CPB }\end{array}$ & $\begin{array}{ll}\text { - } & \text { High diagnostic yield: } \\
\text { - } & \text { Relatively easy to perform } \\
\text { - } & \text { Transthoracic (noninvasive) and } \\
\text { transesophageal (semi-invasive) } \\
\text { - } \quad \text { Direct RV function assessment (TAPSE) } \\
\text { - } \quad \text { Not routinely done for all cardiac patients }\end{array}$ \\
\hline $\begin{array}{c}\text { Natriuretic } \\
\text { Peptides (BNP } \\
\text { and NT-proBNP) }\end{array}$ & $\begin{array}{ll}\text { - } & \text { Heart failure } \\
- & \text { Acute PE } \\
\text { - } & \text { PH } \\
\text { - } & \text { Heart transplant }\end{array}$ & $\begin{array}{ll}\text { - } & \text { LV dysfunction } \\
\text { - } & \text { RV dysfunction } \\
\text { - } & \text { Prognostic information in } \\
& \text { patients with PH or PE }\end{array}$ & - $\quad$ Pre-transplant patients & $\begin{array}{ll}\text { - } & \text { Identifying high-risk patients for } \\
\text { personalized, etiology-specific therapy } \\
\text { - } & \text { Deferral of non-emergency surgery for } \\
\text { decongestive and vasodilator therapy } \\
\text { - } & \text { Monitor response to therapy } \\
\text { - } & \text { Identify high-risk patients for difficult } \\
\text { CPB separation } \\
\text { - } \quad \begin{array}{l}\text { Prioritize patients on transplant waitlists } \\
\text { - }\end{array} \text { Identify high-risk candidates for } \\
\text { enrolment in clinical trials }\end{array}$ \\
\hline $\begin{array}{l}\text { Serum Markers } \\
\text { (transaminases) }\end{array}$ & - Heart failure & $\begin{array}{l}\text { - Differentiate between chronic } \\
\text { and acute HF }\end{array}$ & - $\quad$ Nil & - $\quad$ Nil \\
\hline
\end{tabular}

Abbreviations: MRI—-magnetic resonance imagining; RV—right ventricle; CABG—coronary artery bypass grafting; ICU—intensive care unit; RVF—right ventricular failure; RHC—right heart catheterization; HF-heart failure; $\mathrm{PH}$ - pulmonary artery hypertension; $\mathrm{PA}$ - pulmonary artery; RAP—right atrial pressure; CVP—central venous pressure; LVAD—-left ventricular assist device; PCWP—-pulmonary capillary wedge pressure; PVR—pulmonary vascular resistance; WU—-wood unit; ECHO—echocardiography; CHD—congenital heart disease; $\mathrm{CPB}$ - cardiopulmonary bypass; TAPSE-tricuspid annular plane systolic excursion; BNP—brain natriuretic peptide; NT-proBNP-N-terminal pro-brain natriuretic peptide. 


\section{Biomarkers and Perioperative RV Function}

The limitations in current RV assessment modalities highlight the need for reliable, non-invasive, and cost-effective measures in the perioperative setting. With the advent of precision medicine, there is rising interest in the discovery of biomarkers to fulfill this role [16]. According to the World Health Organization, a biomarker is defined as any substance, structure, or process that can be measured in the body or its products and that influences or predicts the incidence of outcome or disease [27]. Most perioperative biomarker studies have used natriuretic peptides to quantify and predict LV failure [28], and perioperative research on RV biomarkers is lacking [29]. HF biomarkers are generally classified into markers of inflammation, myocyte injury and stress, neurohormonal activation, and extracellular matrix (ECM) turnover. In order for a biomarker to be clinically useful, it must be measurable, provide new information, and be able to assist in clinical decision-making (Table 3) [30]. This review will focus on the first two classes of biomarkers, as they have greater practical potential in the perioperative setting.

Table 3. Properties of a clinically useful biomarker.

\begin{tabular}{cll}
\hline \multicolumn{1}{c}{ Criteria } & & \multicolumn{1}{c}{ Details } \\
\hline Is the biomarker measurable? & - & $\begin{array}{l}\text { Accurate and reproducible methods } \\
\text { Rapid turnaround time } \\
\text { Reasonable cost }\end{array}$ \\
\hline $\begin{array}{c}\text { Does the biomarker provide } \\
\text { new information? }\end{array}$ & - & $\begin{array}{l}\text { Strong and consistent association between biomarker and } \\
\text { outcome or disease in multiple studies } \\
\text { Provides information that is not available from clinical } \\
\text { assessments and adds or improves upon existing tests }\end{array}$ \\
\hline $\begin{array}{c}\text { Will the biomarker assist clinical } \\
\text { decisions making? }\end{array}$ & - & $\begin{array}{l}\text { Superior to other available tests } \\
\text { Assists decision-making and enhances clinical care }\end{array}$ \\
\hline
\end{tabular}

\subsection{Biomarkers of Inflammation}

Tissue injury initiates an inflammatory response in which proinflammatory cytokines are released into the bloodstream to repair damaged tissues [31]. The following inflammatory biomarkers are potentially relevant to the perioperative setting.

\subsubsection{Suppressor of Tumorgenicity 2 (ST2) and Soluble ST2 (sST2)}

ST2 is a member of the IL-1 receptor family and exists in both insoluble membrane-bound and soluble forms (sST2). The binding of ST2 to IL-33 (a mediator of inflammatory disease that is also produced during processes of myocyte stress, hypertrophy, and fibrosis) [31] confers cardioprotection by reducing fibrosis and hypertrophy, ultimately preserving ventricular function [32]. This cardioprotective effect is reversed by the binding of IL-33 to SST2 [31].

High serum levels of sST2 differentiated between HF and non-cardiac etiologies of shortness of breath [33]. In addition, sST2 level weakly correlated with NYHA functional class $(r=0.13)$, LVEF $(r=0.13)$, creatinine clearance $(r=0.22)$, BNP $(r=0.29)$, NT-proBNP $(r=0.41)$, and C-reactive protein $(r=0.43 ; p<0.05)$, one year after acute HF presentation [34]. In patients with acute decompensated $\mathrm{HF}$, a sST2 cutoff value of $>0.49 \mathrm{ng} / \mathrm{mL}$ had $72 \%$ sensitivity, $56 \%$ specificity, and $39 \%$ positive and $84 \%$ negative predictive values for predicting 1-year mortality [34,35]. When a cutoff value of $>0.2 \mathrm{ng} / \mathrm{mL}$ was used, the negative predictive value for 1-year mortality increased to $96 \%$ [35]. In contrast, ST2 $>35 \mathrm{ng} / \mathrm{mL}$ was associated with significantly increased risk of all-cause death or hospitalization (HR, 1.48; $p<0.0001)$, CV death, or HF hospitalization (HR, 2.14; $p<0.0001)$, and all-cause mortality 
(HR, 2.33; $p<0.0001)$ over the 32-month follow-up [36]. Elevated sST2 also predicts death and HF onset within 30 days following acute myocardial infarction (MI) [37-39].

Although circulating levels of sST2 have been implicated in the outcomes of patients with LV failure [36], recent studies suggest these levels may reflect responses of the RV to congestion [40,41]. Zheng et al. found correlations between sST2 levels and PH disease severity and clinical deterioration [42]. Expanding on these findings, Broch et al. examined patients with isolated arrhythmogenic RV cardiomyopathy and found an association between SST2 and RV function and arrhythmia load [43]. Ojji et al. also found correlations between SST2 and RV systolic pressure, diastolic diameter, and right atrial area in a cohort of hypertensive HF patients [44].

In summary, ST2 and sST2 are potential biomarkers of RV remodeling and may have a role in predicting short- and long-term mortality in those undergoing cardiac surgery [30]. Being unaffected by age, BMI, atrial fibrillation, HF, the specific cause of cardiomyopathy (i.e., ischemic vs. non-ischemic), and analytical interference by bilirubin, hemoglobin, triglycerides, cholesterol, or total protein [34], these biomarkers may be more specific than natriuretic peptides in detecting RVF and should be investigated in the perioperative setting.

\subsubsection{Galectin 3 (Gal-3)}

Gal-3 is a macrophage product member of the lectins family, which is a group of proteins that interact specifically with carbohydrate sugars beta-galactosides $[16,30]$. Galectins play an important role in immune and inflammatory responses [45], wound repair [46], and pathways that regulate cardiac contractility and inflammatory cascades following injury [16]. Gal-3 is abundant in the spleen, lung, stomach, colon, and uterus, while normally expressed in lower amounts in the kidneys, pancreas, liver, and heart [47]. Significant increases in Gal-3 levels in the latter organs are correlated with pathophysiological states.

Cardiac remodeling is an essential feature of HF and is closely linked to disease progression [30]. Fibroblasts and macrophages are responsible for the initiation and progression of tissue fibrosis [48], and the expression of Gal-3 is increased in activated macrophages, which stimulates the maladaptive pathological cardiac responses such as remodeling, fibroblast proliferation, and collagen deposition [49]. Sharma et al. first described the Gal-3 gene expression in rat HF models and observed considerable collagen deposition with pericardial installation of Gal-3 [49]. The PRIDE study was the first to measure Gal-3 in humans [50], noting higher levels in patients with HF than those without (median $9.2 \mathrm{ng} / \mathrm{mL}$ vs. $6.9 \mathrm{ng} / \mathrm{mL}, p<0.001$ ). A study comparing NT-proBNP and Gal-3 in diagnosing acute HF demonstrated that, while NT-proBNP afforded more diagnostic accuracy for HF (with an area under curve (AUC) of 0.94 for NT-proBNP, $p<0.0002$, and an AUC of 0.72 for Gal-3, $p<0.0001$ ), Gal-3 was the strongest predictor of 60-day mortality (OR 10.3, 95\% CI 1.6-174.1, $p<0.01$ ) or a combination of death/recurrent HF within 60 days (OR 14.3, 95\% CI 5.6-45, $p<0.001$ ) [51]. In addition, the combined elevation of Gal-3 and NT-proBNP was a stronger predictor of mortality than either alone $(p<0.05)[51,52]$. Gruson et al. showed that Gal-3 levels correlated with LV failure severity [53]. In addition, a cutoff of $>19.2 \mathrm{ng} / \mathrm{mL}$ predicted long-term cardiovascular death, provided incremental prognostic information to BNP, and was a cost-effective means of reducing the length of hospital stay [53].

Milting et al. highlighted the possible utility of plasma Gal-3 as a biomarker of RV function in patients with advanced HF requiring LVAD support. In this study, the presence of LVAD reduced plasma BNP, deeming it impractical in prognostication. However, elevated plasma Gal-3 were observed in patients who died compared to those who survived to transplantation [30]. These findings were corroborated by de Boer et al., who found Gal-3 to be an independent predictor of adverse outcomes (all-cause mortality and HF hospitalization) in HF patients (HR 1.38, 95\% CI 1.07-1.78, $p=0.015$ ), especially those with preserved LVEF [52].

Gal-3 also correlates with RV function in the context of isolated PH. PH leads to both morphological and functional changes to the RV including contractile function, chamber size, hypertrophy, and changes in the ECM [54], all of which occur in the absence of LV failure. Fenster et al. found that serum 
Gal-3 levels were significantly elevated in PH subjects than controls and that Gal-3 correlated with RVEF $(r=-0.44, p=0.03)$, end diastolic volume index $(r=0.42, p=0.03)$, end systolic volume index $(r=0.44, p=0.027)$, mass index $(r=0.47, p=0.016)$, systolic pressure $(r=0.55, p<0.001)$, and strain $(r=0.43, p=0.03)[54]$.

The potential utility of Gal-3 has not been studied in the perioperative context. In addition to being a marker of LV failure, Gal-3 has clearly been shown to correlate with RV function in the absence of LV failure, making it a promising RV biomarker for cardiac surgery patients. Possible areas of investigation include risk stratification and prognostication in patients receiving LVADs, as well as in $\mathrm{PH}$ patients requiring cardiac surgery.

\subsubsection{C-Reactive Protein (CRP)}

CRP is a non-specific acute phase reactant that is predominantly produced by the liver and released into the bloodstream within minutes of inflammatory processes such as tissue injury and infection [55]. Although nonspecific, CRP has been used to assess patients with HF [56], PH [57], and PE [58]. In a study of PH patients, Quarck et al. showed correlations between CRP and NYHA class $(r=0.23)$, $\operatorname{RAP}(r=0.25)$, and 6-min walking distance $(r=-0.19)$. In addition, CRP was found to be significantly higher in non-survivors than in survivors $(p=0.003)$ [57]. These authors concluded that CRP has a role in predicting outcomes and response to therapy in PH patients. CRP has also been linked to survival in the setting of acute PE, with higher levels being observed in those with RV dysfunction and death [58]. The positive correlation between CRP, RAP, and the degree of RV dysfunction points to its possible utility as a prognostic marker in the settings of $\mathrm{PH}$ and acute PE $[57,58]$. This notion is further supported by findings of the large Multi-Ethnic Study of Atherosclerosis Right Ventricle Study, where elevated CRP may be linked to negative RV structural changes [56,59]. In summary, serum CRP is a rapid, readily available assay that may have practical value in the assessment of perioperative RV function and prognostication.

\subsection{Biomarkers of Myocyte Injury and Stretch}

\subsubsection{Cardiac Troponins}

Cardiac troponins (cTn) have traditionally been used in the diagnosis of MI but may also be elevated in the setting of HF [60]. In the setting of acute PE, elevated cTn predicted RV hypokinesis and mortality [61,62] and correlated more strongly with future risk of HF than ischemic events [63]. Optimal cutoff value for predicting RV hypokinesis in this context is $0.1 \mathrm{ng} / \mathrm{mL}[62,64]$. The major drawback of cTn as a RV biomarker is its lack of specificity, especially in the presence of chronic stable CAD or concomitant renal disease.

\subsubsection{High Sensitivity Troponin (hs-cTn)}

Hs-cTn is a more sensitive predictor of mortality and readmissions in both stable and acute decompensated HF $[60,65]$. The utility of this assay in detecting RVF has only been explored in small studies in non-operative settings. Specifically, elevated hs-cTn levels are associated with RV dysfunction in patients with acute PE [66]. In addition, in the setting of PH, hsTn levels increase specifically in proportion to the severity of RV dysfunction [67]. In patients with previous Tetrology of Fallot repair, hs-cTn increases specifically with increasing RV volume and worsening RVEF [68]. In the setting of coronary artery bypass grafting (CAPG), elevated hs-cTn is associated with postoperative MI, the need for vasopressor support, prolonged mechanical ventilation, an increased intensive care unit (ICU) length of stay, and mortality [69]. The predictive and diagnostic utility of hs-cTn should be investigated in patients undergoing cardiac surgery, as it may provide information on postoperative recovery. 


\subsubsection{Natriuretic Peptides}

To date, only BNP and its precursor NT-proBNP have been validated for clinical use in HF patients [70]. Current HF guidelines recommend monitoring of BNP or NT-proBNP levels not only for diagnosis, but also for monitoring disease progression and prognosis [30]. However, conditions such as age, sex, renal function, body mass index, and anemia confound the observed BNP and NT-proBNP values [71].

BNP is transcribed and produced in ventricular myocytes, [72] in response to shear stress and myocardial stretch in pressure or volume overloaded states [16]. It counteracts maladaptive responses to volume homeostasis and peripheral vascular resistance by inducing natriuresis, diuresis, and vasodilation [73]. BNP production is normally about $10 \mathrm{pg} / \mathrm{mL}$ in healthy individuals [74]. Under conditions of increased myocardial stretch, the pre-proBNP is upregulated and cleaved into the more stable, biologically active BNP and NT-proBNP [16]. In patients presenting to the emergency department with acute dyspnea, elevated BNP differentiated HF from other causes of dyspnea (AUC 0.91), and BNP levels correlated directly with HF severity [75].

NT-proBNP is a better diagnostic test than BNP due to its longer half-life (70 min vs. $20 \mathrm{~min}$ ) and thus higher plasma concentrations [16]. It has a greater negative predictive value for acute HF compared to BNP and has an optimal cutoff value of $300 \mathrm{pg} / \mathrm{mL}$ [75]. NT-proBNP is also superior to $\mathrm{BNP}$ as a predictor of survival in PH patients due to its ability to reflect the degree of hemodynamic impairment while being unaffected by the presence of renal insufficiency, which is a beneficial feature in the perioperative setting [76].

In the acute cardiac surgical setting, preoperative BNP is associated with early outcomes in terms of: ICU length of stay, duration of postoperative mechanical ventilation, and inotropic support [77]. In fact, several studies found BNP and NT-proBNP to be better predictors of nonfatal cardiac events, ICU length of stay, and all-cause in-hospital mortality following cardiac surgery than the well-established EuroSCORE [78,79]. The addition of NT-proBNP to EuroSCORE II also improved the clinician's ability to predict severe circulatory failure following isolated CABG for ACS [80].

$\mathrm{RV}$ dysfunction has been implicated in reduced exercise capacity [81] and cardiovascular death [82] in both idiopathic and ischemic cardiomyopathy [15]. Natriuretic peptides are elevated specifically in patients with RV dysfunction in a variety of clinical settings. In the setting of PE and preserved LV systolic function, BNP was elevated specifically in those who developed RV dysfunction [83]. A meta-analysis in the setting of acute PE also found BNP and NT-proBNP to be elevated in patients with RV dysfunction, and that these biomarkers predicted complicated in-hospital course (OR 6.8, 95\% CI 4.4-10) and 30-day mortality (OR 7.6, 95\% CI 3.4-17) [84]. In the setting of PH, BNP, and NT-proBNP increase specifically in proportion to the degree of RV distension and wall stress, thus providing important prognostic information $[15,85,86]$. Thus, higher BNP levels are independently correlated with mortality, RV pressure or volume overload, and reduced RV EF in this setting $[15,31,86]$. In HF patients with comparable LVEF, Passino et al. found higher BNP levels in the presence of RV volume overload and dysfunction and concluded that there was an inverse relationship between RVEF and natriuretic peptides levels [15].

NT-proBNP provides a simple and effective snapshot of RV cellular function and correlates well with the gold standard cardiac MRI [85]. Its role in predicting and detecting RVF warrants further exploration in the full scope of cardiac surgery practice, especially in light of widely adopted perioperative measures of RV function and volume status such as TEE and CVP.

\subsubsection{ANP}

ANP has also been implicated in the diagnosis and prognosis of patients with RV dysfunction $[15,86]$. ANP is secreted by the atria in healthy individuals and by the LV in patients with LV dysfunction [87]. Like BNP, ANP is a counter-regulatory hormone that functions as vasodilator, natriuretic peptide, and inhibitor of the renin-angiotensin-aldosterone system [86]. Persistently elevated ANP levels were evident in HF refractory to treatment, while decreasing ANP trends were observed in 
those who responded to therapy [88]. Elevated ANP levels have previously been described in isolated RV dysfunction in the context of PH [89] and PE [90]. However, ANP is less sensitive and specific than BNP in detecting RVF, making it less desirable as a target for perioperative research [91].

\section{Implications for Research and Clinical Practice}

The incorporation of biomarkers in the perioperative management of cardiac surgery patients represents a promising strategy to improve patient care. To date, RV-specific biomarkers have not yet been identified in the perioperative setting [29], and this presents an opportunity for future research. We suggest that the potential utility of ST2, sST2, Gal-3, CRP, hs-cTn, and NT-proBNP in predicting and detecting RVF be explored and validated for use in conjunction with other diagnostic modalities such as echocardiography and RHC. The addition of biomarkers can provide objective measures of RV function, and help to overcome the limitations of existing modalities such as inter-observer variability in the visual estimate of RV function by echo and the invasiveness of RHC. This proposed multimodal approach can provide a rapid, inexpensive, and comprehensive snapshot of RV structure, function and the state of venous congestion (Table 4). In addition, serial biomarker measurements may assist in monitoring response to therapy, assessing whether a patient is optimized for surgery, and administering personalized interventions perioperatively and in long-term follow up.

Current data support the role of serum ST2, sST2, and Gal-3 as markers of RVF in the presence of preserved LVEF and/or adequate LV mechanical circulatory support (MCSP), and similar investigations need to be extended to the perioperative setting. For instance, ST2 may help to differentiate cardiovascular vs. non-cardiovascular causes of shortness of breath and hypoxemia in the postoperative patient and to predict and detect acute RVF and common RVF-associated complications and death. Gal-3 has already been shown to be highly reflective of RVF in cardiac surgery patients requiring MCSP [92,93], holding promise as a marker to help prioritize transplant listings and provide personalized, goal-directed perioperative management to prevent and treat RVF in high-risk patients. It is to be noted that these biomarkers are still in the investigative phase and are limited by the practicality of their assay kits. For instance, the traditional 96-well ELISA plates may not be run frequently, as enough samples would have to be gathered before each run. The advent of rapid point of care ST2, sST2 [94], and Gal-3 assays [53] brings the promise of a shortened processing time (20 min), thus allowing clinicians to react more promptly based on these test results.

CRP and hs-cTn are a routine part of many clinical practices. Both have rapid laboratory turnaround times, are relatively inexpensive to measure, and have the ability to predict mortality and acute RVF in at-risk non-surgical populations such as those with acute PE. These qualities raise the possibility of using these biomarkers to rapidly confirm suspected cases of acute RVF post-cardiac surgery, thus allowing timely interventions. Potential drawbacks such as a lack of specificity for RVF will also need to be investigated in the perioperative setting.

NT-proBNP has been shown to correlate with the gold standard cardiac MRI measurement of RV morphology and function. Serum NT-proBNP can be measured rapidly in the laboratory and by using a reliable and inexpensive point of care assay. Observational studies have already shown the utility of this biomarker in acute perioperative RVF, and in risk stratifying patients with circulatory failure post-CABG. Further studies need to focus on validation in a broader range of cardiac procedures and to determine whether serial perioperative NT-proBNP measurements would lead to improved outcomes and reduced healthcare cost. 
Table 4. RV specific biomarkers.

\begin{tabular}{|c|c|c|}
\hline Biomarker & RV Specific Uses & Non-RV Uses \\
\hline \multicolumn{3}{|l|}{$\begin{array}{l}\text { Biomarkers of } \\
\text { Inflammation }\end{array}$} \\
\hline ST2 and sST2 & $\begin{array}{l}\text { - Correlation with PH disease severity } \\
\text { and clinical deterioration } \\
\text { - Increased levels associated with isolated } \\
\text { arrhythmogenic RV cardiomyopathy } \\
\text { - Significant correlations between soluble } \\
\text { sST2 and RV systolic pressure, diastolic } \\
\text { diameter, and right atrial area have } \\
\text { been shown } \\
\text { - Yet to be studied in RV prognostication } \\
\text { in cardiac surgery patients }\end{array}$ & $\begin{array}{l}\text { Differentiate dyspnea caused by } \\
\text { HF vs. } \\
\text { noncardiovascular etiologies } \\
\text { Prognostic value in aiding risk } \\
\text { stratification of heart failure } \\
\text { patients at high risk of mortality } \\
\text { and rehospitalization } \\
\text { - } \quad \text { HF prediction post ACS }\end{array}$ \\
\hline Galectin 3 & $\begin{array}{l}\text { - } \quad \text { Biomarker for RV function in patients on } \\
\text { LVAD support } \\
\text { - Gal-3 is well correlated with RV function } \\
\text { in the context of isolated PH }\end{array}$ & $\begin{array}{l}\text { - Diagnosing acute HF and } \\
\text { assessing severity of HF based } \\
\text { on NYHA } \\
\text { - } \quad \text { Strong predictor of mortality and } \\
\text { recurrent HF }\end{array}$ \\
\hline CRP & $\begin{array}{l}\text { - High levels are associated with RV } \\
\text { dysfunctional and mortality in acute PE } \\
\text { - Systemic inflammation as measured by } \\
\text { CRP has been shown to specifically } \\
\text { contribute to negative RV } \\
\text { structural changes }\end{array}$ & $\begin{array}{l}\text { - Used to asses patients with } \mathrm{HF} \text {, } \\
\mathrm{PH} \text {, and PE }\end{array}$ \\
\hline
\end{tabular}

\begin{tabular}{|c|c|c|}
\hline $\begin{array}{l}\text { Biomarkers of Myocyte } \\
\text { Injury \& Stress }\end{array}$ & & \\
\hline $\begin{array}{l}\text { High Sensitivity } \\
\text { Troponins }\end{array}$ & 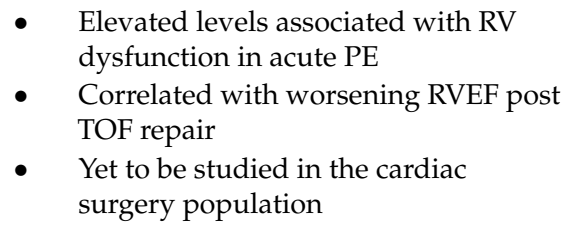 & - $\quad$ Diagnosing acute MI \\
\hline BNP and NT-proBNP & $\begin{array}{l}\text { - Elevated in patients with RV } \\
\text { dysfunction in the setting of PE and PH } \\
\text { Elevated levels in patients with } \\
\text { comparable LVEF in the presence of } \\
\text { RV dysfunction } \\
\text { - Yet to be studied in RV prognostication } \\
\text { in cardiac surgery patients }\end{array}$ & $\begin{array}{l}\text { Diagnosing and monitoring } \\
\text { disease progression in } \\
\text { HF patients } \\
\text { Predictors of length of stay, } \\
\text { inotropic support, and } \\
\text { postoperative mechanical } \\
\text { ventilation support in acute } \\
\text { cardiac surgical setting }\end{array}$ \\
\hline
\end{tabular}

Abbreviations: PH—pulmonary artery hypertension; HF-heart failure; RV—right ventricular; ACS—acute coronary syndrome; LVAD—left ventricular assist device; CRP $-\mathrm{C}$ reactive protein; NYHA—new york heart association; $\mathrm{PE}$ - pulmonary embolism; BNP—brain natriuretic protein; MI-myocardial infarction; NT-proBNP-N-terminal pro-brain natriuretic peptide; LVEF-left ventricular ejection fraction.

\section{Conclusions}

Perioperative RVF is associated with increased mortality, morbidity, and healthcare cost [21]. Cardiac surgical patients are a susceptible group in whom objective, reproducible, and non-invasive diagnostic measures of RV function are needed. Biomarkers offer rapid, unbiased and non-invasive molecular level insight that may be used to inform personalized, etiology-specific therapy in the face of rapidly evolving perioperative physiology. Our review has identified several biomarkers whose role in 
the assessment and management RVF deserve further investigation in the perioperative setting. These biomarkers may prove to be useful in identifying high-risk patients for personalized, etiology-specific therapy, to monitor the state of preoperative optimization and perioperative response to therapy, as well as to supplement RHC and echocardiograms in establishing transplant priority and eligibility for LVAD therapy. A single biomarker measurement may alert clinicians of the need to initiate RV-specific therapy early, to prevent clinical deterioration and end organ failure. This may ultimately lead to shortened ICU and hospital lengths of stay, reduce the need for unplanned RV mechanical support, and improve patient outcomes while minimizing healthcare cost.

Author Contributions: L.Y.S. conceived the study; H.J. and L.Y.S. performed the literature search and drafted the manuscript; all authors participated in the critical revision and approval of the manuscript.

Conflicts of Interest: The authors declare no conflict of interest.

\section{Abbreviations}

\section{Variable}

RV

RVF

$\mathrm{HF}$

CVP

RAP

CPB

$\mathrm{PH}$

PE

VAD (LVAD/RVAD)

BNP/NT-pro-BNP

\author{
Definition \\ right ventricular \\ right ventricular failure \\ heart failure \\ central venous pressure \\ right atrial pressure \\ cardiopulmonary bypass \\ pulmonary hypertension \\ pulmonary embolism \\ ventricular assist device (left/right) \\ brain natriuretic peptide, $\mathrm{N}$-terminal pro-brain natriuretic peptide
}

\section{References}

1. Haddad, F.; Doyle, R.; Murphy, D.J.; Hunt, SA. Right ventricular function in cardiovascular disease, part II: pathophysiology, clinical importance, and management of right ventricular failure. Circulation 2008, 117, 1717-1731. [CrossRef]

2. Denault, A.Y.; Haddad, F.; Jacobsohn, E.; Deschamps, A. Perioperative right ventricular dysfunction. Curr. Opin. Anaesthesiol. 2013, 26, 71-81. [CrossRef] [PubMed]

3. Costachescu, T.; Denault, A.; Guimond, J.-G.; Couture, P.; Carignan, S.; Sheridan, P.; Hellou, G.; Blair, L.; Normandin, L.; Babin, D.; et al. The hemodynamically unstable patient in the intensive care unit: Hemodynamic vs. transesophageal echocardiographic monitoring. Crit. Care Med. 2002, 30, 1214-1223. [CrossRef] [PubMed]

4. Lahm, T.; McCaslin, C.A.; Wozniak, T.C.; Ghumman, W.; Fadl, Y.Y.; Obeidat, O.S.; Schwab, K.; Meldrum, D.R. Medical and Surgical Treatment of Acute Right Ventricular Failure. J. Am. Cardiol. 2010, 56, 1435-1446. [CrossRef]

5. Reichert, C.L.; Visser, C.A.; Brink, R.B.V.D.; Koolen, J.J.; Van Wezel, H.B.; Moulijn, A.C.; Dunning, A.J. Prognostic value of biventricular function in hypotensive patients after cardiac surgery as assessed by transesophageal echocardiography. J. Cardiothorac. Vasc. Anesthesia 1992, 6, 429-432. [CrossRef]

6. Vizzardi, E.; D'Aloia, A.; Caretta, G.; Bordonali, T.; Bonadei, I.; Rovetta, R.; Quinzani, F.; Bugatti, S.; Curnis, A.; Metra, M. Long-term prognostic value of longitudinal strain of right ventricle in patients with moderate heart failure. Hell. J. Cardiol. 2014, 55, 150-155.

7. Schmid, E.; Hilberath, J.N.; Blumenstock, G.; Shekar, P.S.; Kling, S.; Shernan, S.K.; Rosenberger, P.; Nowak-Machen, M. Tricuspid annular plane systolic excursion (TAPSE) predicts poor outcome in patients undergoing acute pulmonary embolectomy. Hear. lung Vessel. 2015, 7, 151-158.

8. Pruszczyk, P.; Goliszek, S.; Lichodziejewska, B.; Kostrubiec, M.; Ciurzyński, M.; Kurnicka, K.; Dzikowska-Diduch, O.; Palczewski, P.; Wyzgal, A. Prognostic Value of Echocardiography in Normotensive Patients with Acute Pulmonary Embolism. JACC: Cardiovasc. 2014, 7, 553-560. [CrossRef] [PubMed] 
9. Greyson, C.R. Pathophysiology of right ventricular failure. Crit. Care Med. 2008, 36, S57-S65. [CrossRef] [PubMed]

10. Kubba, S.; Davila, C.D.; Forfia, P.R. Methods for Evaluating Right Ventricular Function and Ventricular-Arterial Coupling. Prog. Cardiovasc. Dis. 2016, 59, 42-51. [CrossRef]

11. Marzec, L.N.; Ambardekar, A.V. Preoperative Evaluation and Perioperative Management of Right Ventricular Failure After Left Ventricular Assist Device Implantation. Semin. Cardiothorac. Vasc. Anesthesia 2013, 17, 249-261. [CrossRef]

12. Denault, A.Y.; Bussières, J.S.; Arellano, R.; Finegan, B.; Gavra, P.; Haddad, F.; Nguyen, A.Q.; Varin, F.; Fortier, A.; Levesque, S.; et al. A multicentre randomized-controlled trial of inhaled milrinone in high-risk cardiac surgical patients. Can. J. Anesth. 2016, 63, 1140-1153. [CrossRef]

13. Borlaug, B.A.; Kass, D.A. Invasive Hemodynamic Assessment in Heart Failure. Hear. Fail. Clin. 2009, 5, 217-228. [CrossRef] [PubMed]

14. Voelkel, N.F.; Quaife, R.A.; Leinwand, L.A.; Barst, R.J.; McGoon, M.D.; Meldrum, D.R.; Dupuis, J.; Long, C.S.; Rubin, L.J.; Smart, F.W.; et al. Right Ventricular Function and Failure: Report of a National Heart, Lung, and Blood Institute Working Group on Cellular and Molecular Mechanisms of Right Heart Failure. Circulation 2006, 114, 1883-1891. [CrossRef] [PubMed]

15. Passino, C.; Sironi, A.M.; Favilli, B.; Poletti, R.; Prontera, C.; Ripoli, A.; Lombardi, M.; Emdin, M. Right heart overload contributes to cardiac natriuretic hormone elevation in patients with heart failure. Int. J. Cardiol. 2005, 104, 39-45. [CrossRef]

16. Gaggin, H.K.; Januzzi, J.L. Biomarkers and diagnostics in heart failure. Biochim. et Biophys. N.a. (BBA)—Mol. Basis 2013, 1832, 2442-2450. [CrossRef]

17. Simon, M.A. Assessment and treatment of right ventricular failure. Nat. Rev. Cardiol. 2013, 10, $204-218$. [CrossRef]

18. Lang, R.M.; Badano, L.P.; Mor-Avi, V.; Afilalo, J.; Armstrong, A.; Ernande, L.; Flachskampf, F.A.; Foster, E.; Goldstein, S.A.; Kuznetsova, T.; et al. Recommendations for Cardiac Chamber Quantification by Echocardiography in Adults: An Update from the American Society of Echocardiography and the European Association of Cardiovascular Imaging. J. Am. Soc. Echocardiogr. 2015, 16, 233-271. [CrossRef]

19. Buckberg, G.; Hoffman, J.I. Right ventricular architecture responsible for mechanical performance: Unifying role of ventricular septum. J. Thorac. Cardiovasc. Surg. 2014, 148, 3166-3171. [CrossRef]

20. Pinedo, M.; Villacorta, E.; Tapia, C.; Arnold, R.; Lopez, J.; Revilla, A.; Gómez, I.; Fulquet, E.; Román, J.A.S. Inter- and Intra-Observer Variability in the Echocardiographic Evaluation of Right Ventricular Function. Revista Española de Cardiología (English Edition) 2010, 63, 802-809. [CrossRef]

21. Konstam, M.A.; Kiernan, M.S.; Bernstein, D.; Bozkurt, B.; Jacob, M.; Kapur, N.K.; Kociol, R.D.; Lewis, E.F.; Mehra, M.R.; Pagani, F.D.; et al. Evaluation and Management of Right-Sided Heart Failure: A Scientific Statement From the American Heart Association. Circulation 2018, 137, e578-e622. [CrossRef] [PubMed]

22. Lupi, E.; Dumont, C.; Tejada, V.M.; Horwitz, S.; Golland, F.; Galland, F. A Radiologic Index of Pulmonary Arterial Hypertension. Chest 1975, 68, 28-31. [CrossRef] [PubMed]

23. Atluri, P.; Goldstone, A.B.; Fairman, A.S.; MacArthur, J.W.; Shudo, Y.; Cohen, J.E.; Acker, A.L.; Hiesinger, W.; Howard, J.L.; Acker, M.A.; et al. Predicting Right Ventricular Failure in the Modern, Continuous Flow Left Ventricular Assist Device Era. Ann. Thorac. Surg. 2013, 96, 857-864. [CrossRef]

24. Taghavi, S.; Zuckermann, A.; Ankersmit, J.; Wieselthaler, G.; Rajek, A.; Laufer, G.; Wolner, E.; Grimm, M. Extracorporeal Membrane Oxygenation is Superior to Right Ventricular Assist Device for Acute Right Ventricular Failure After Heart Transplantation. Ann. Thorac. Surg. 2004, 78, 1644-1649. [CrossRef] [PubMed]

25. Lopez-Sendon, J.; Coma-Canella, I.; Gamallo, C. Sensitivity and specificity of hemodynamic criteria in the diagnosis of acute right ventricular infarction. Circulation 1981, 64, 515-525. [CrossRef]

26. Nagendran, J.; Gurtu, V.; Fu, D.Z.; Dyck, J.R.; Haromy, A.; Ross, D.B.; Rebeyka, I.M.; Michelakis, E.D. A dynamic and chamber-specific mitochondrial remodeling in right ventricular hypertrophy can be therapeutically targeted. J. Thorac. Cardiovasc. Surg. 2008, 136, 168-178. [CrossRef] [PubMed]

27. Biomarkers Definitions Working Group. Biomarkers and surrogate endpoints: Preferred definitions and conceptual framework. Clin. Pharmacol. Ther. 2001, 69, 89-95. [CrossRef] [PubMed] 
28. Hellman, Y.; Malik, A.S.; Lin, H.; Shen, C.; Wang, I.W.; Wozniak, T.C.; Hashmi, Z.A.; Shaukat, A.; Pickrell, J.; Caccamo, M.A.; et al. B-type natriuretic peptide-guided therapy and length of hospital stay post left ventricular assist device implantation. ASAIO J. 2015, 61, 156-160. [CrossRef]

29. Di Salvo, T.G.; Yang, K.-C.; Brittain, E.; Absi, T.; Maltais, S.; Hemnes, A. Right Ventricular Myocardial Biomarkers in Human Heart Failure. J. Fail. 2015, 21, 398-411. [CrossRef]

30. Vondráková, D.; Málek, F.; Ošt'ádal, P.; Kru“ger, A.; Neužil, P. New biomarkers and heart failure. Cor et Vasa 2013, 55, e345-e354. [CrossRef]

31. Chow, S.L.; Maisel, A.S.; Anand, I.; Bozkurt, B.; De Boer, R.A.; Felker, G.M.; Fonarow, G.C.; Greenberg, B.; Januzzi, J.L.; Kiernan, M.S.; et al. Role of Biomarkers for the Prevention, Assessment, and Management of Heart Failure: A Scientific Statement From the American Heart Association. Circulation 2017, 135, e1054-e1091. [CrossRef]

32. Sanada, S.; Hakuno, D.; Higgins, L.J.; Schreiter, E.R.; McKenzie, A.N.; Lee, R.T. IL-33 and ST2 comprise a critical biomechanically induced and cardioprotective signaling system. J. Clin. Investig. 2007, 117, 1538-1549. [CrossRef] [PubMed]

33. Januzzi, J.L., Jr.; Peacock, W.F.; Maisel, A.S.; Chae, C.U.; Jesse, R.L.; Baggish, A.L.; O’Donoghue, M.; Sakhuja, R.; Chen, A.A.; van Kimmenade, R.R.; et al. Measurement of the interleukin family member ST2 in patients with acute dyspnea: Results from the PRIDE (Pro-Brain Natriuretic Peptide Investigation of Dyspnea in the Emergency Department) study. J. Am. Coll. Cardiol. 2007, 50, 607-613. [CrossRef]

34. Rehman, S.U.; Mueller, T.; Januzzi, J.L. Characteristics of the Novel Interleukin Family Biomarker ST2 in Patients With Acute Heart Failure. J. Am. Cardiol. 2008, 52, 1458-1465. [CrossRef] [PubMed]

35. Shah, R.V.; Januzzi, J.L. ST2: A Novel Remodeling Biomarker in Acute and Chronic Heart Failure. Hear. Fail. Rep. 2010, 7, 9-14. [CrossRef] [PubMed]

36. Ky, B.; French, B.; McCloskey, K.; Rame, J.E.; McIntosh, E.; Shahi, P.; Dries, D.L.; Tang, W.H.; Wu, A.H.; Fang, J.C.; et al. High-sensitivity ST2 for prediction of adverse outcomes in chronic heart failure. Circ. Heart Fail. 2011, 4, 180-187. [CrossRef] [PubMed]

37. Bhardwaj, A.; Januzzi, J.L., Jr. ST2, a novel biomarker for heart failure. Expert Rev. Mol. Diagn. 2010, 10, 459-464. [CrossRef]

38. Shimpo, M.; Morrow, D.; Weinberget, E. Serum levels of the interleukin-1 receptor family member ST2 predict mortality and clinical outcome in acute myocardial infarction. ACC J. 2004, 109, 2186-2190.

39. Sabatine, M.S.; Morrow, D.A.; Higgins, L.J.; MacGillivray, C.; Guo, W.; Bode, C.; Rifai, N.; Cannon, C.P.; Gerszten, R.E.; Lee, R.T. Complementary Roles for Biomarkers of Biomechanical Strain ST2 and N-Terminal Prohormone B-Type Natriuretic Peptide in Patients With ST-Elevation Myocardial Infarction. Circulation 2008, 117, 1936-1944. [CrossRef]

40. Broch, K.; Andreassen, A.K.; Ueland, T.; Michelsen, A.E.; Stueflotten, W.; Aukrust, P.; Aakhus, S.; Gullestad, L. Soluble ST2 reflects hemodynamic stress in non-ischemic heart failure. Int. J. Cardiol. 2015, 179, 378-384. [CrossRef]

41. Bartunek, J.; Delrue, L.; Van Durme, F.; Muller, O.; Casselman, F.; De Wiest, B.; Croes, R.; Verstreken, S.; Goethals, M.; De Raedt, H.; et al. Non-Myocardial Production of ST2 Protein in Human Hypertrophy and Failure is Related to Diastolic Load. J. Am. Cardiol. 2008, 52, 2166-2174. [CrossRef]

42. Zheng, Y.-G.; Yang, T.; He, J.-G.; Chen, G.; Liu, Z.-H.; Xiong, C.-M.; Gu, Q.; Ni, X.-H.; Zhao, Z.-H. Plasma Soluble ST2 Levels Correlate With Disease Severity and Predict Clinical Worsening in Patients With Pulmonary Arterial Hypertension. Clin. Cardiol. 2014, 37, 365-370. [CrossRef]

43. Broch, K.; Leren, I.S.; Saberniak, J.; Ueland, T.; Edvardsen, T.; Gullestad, L.; Haugaa, K.H. Soluble ST2 is associated with disease severity in arrhythmogenic right ventricular cardiomyopathy. Biomarkers 2017, 22, 367-370. [CrossRef]

44. Ojji, D.B.; Lecour, S.; Adeyemi, O.M.; Sliwa, K. Soluble ST2 correlates with some indicators of right ventricular function in hypertensive heart failure. Vasc. Heal. Risk Manag. 2017, 13, 311-316. [CrossRef]

45. Sano, H.; Hsu, D.K.; Apgar, J.R.; Yu, L.; Sharma, B.B.; Kuwabara, I.; Izui, S.; Liu, F.T. Critical role of galectin-3 in phagocytosis by macrophages. J. Clin. Invest. 2003, 112, 389-397. [CrossRef]

46. Yang, R.-Y.; Rabinovich, G.A.; Liu, F.-T. Galectins: structure, function and therapeutic potential. Expert Rev. Mol. Med. 2008, 10, e17. [CrossRef]

47. Kim, H.; Lee, J.; Hyun, J.W.; Park, J.W.; Joo, H.; Shin, T. Expression and immunohistochemical localization of galectin-3 in various mouse tissues. Cell Boil. Int. 2007, 31, 655-662. [CrossRef] 
48. Brown, R.D.; Ambler, S.K.; Mitchell, M.D.; Long, C.S. THE CARDIAC FIBROBLAST: Therapeutic Target in Myocardial Remodeling and Failure. Annu. Pharmacol. Toxicol. 2005, 45, 657-687. [CrossRef]

49. Sharma, U.C. Galectin-3 Marks Activated Macrophages in Failure-Prone Hypertrophied Hearts and Contributes to Cardiac Dysfunction. Circulation 2004, 110, 3121-3128. [CrossRef]

50. Januzzi, J.L.; Camargo, C.A.; Anwaruddin, S.; Baggish, A.L.; Chen, A.A.; Krauser, D.G.; Tung, R.; Cameron, R.; Nagurney, J.T.; Chae, C.U.; et al. The N-terminal Pro-BNP Investigation of Dyspnea in the Emergency department (PRIDE) study. Am. J. Cardiol. 2005, 95, 948-954. [CrossRef]

51. Van Kimmenade, R.R.; Januzzi, J.L.; Ellinor, P.T.; Sharma, U.C.; Bakker, J.A.; Low, A.F.; Martinez, A.; Crijns, H.J.; Macrae, C.A.; Menheere, P.P.; et al. Utility of Amino-Terminal Pro-Brain Natriuretic Peptide, Galectin-3, and Apelin for the Evaluation of Patients with Acute Heart Failure. J. Am. Cardiol. 2006, 48, 1217-1224. [CrossRef] [PubMed]

52. de Boer, R.A.; Lok, D.J.; Jaarsma, T.; van der Meer, P.; Voors, A.A.; Hillege, H.L.; van Veldhuisen, D.J. Predictive value of plasma galectin-3 levels in heart failure with reduced and preserved ejection fraction. Ann. Med. 2011, 43, 60-68. [CrossRef] [PubMed]

53. Gruson, D.; Mancini, M.; Ahn, S.; Rousseau, M. Measurement of Galectin-3 with the ARCHITECT assay: Clinical validity and cost-effectiveness in patients with heart failure. Clin. Biochem. 2014, 47, 1006-1009. [CrossRef] [PubMed]

54. Fenster, B.E.; Lasalvia, L.; Schroeder, J.D.; Smyser, J.; Silveira, L.J.; Buckner, J.K.; Brown, K.K. Galectin-3 levels are associated with right ventricular functional and morphologic changes in pulmonary arterial hypertension. Heart Vessels 2016, 31, 939-946. [CrossRef] [PubMed]

55. Yoshinaga, R.; Doi, Y.; Ayukawa, K.; Ishikawa, S. High-sensitivity C reactive protein as a predictor of inhospital mortality in patients with cardiovascular disease at an emergency department: a retrospective cohort study. BMJ Open 2017, 7, e015112. [CrossRef] [PubMed]

56. Harhay, M.O.; Tracy, R.P.; Bagiella, E.; Barr, R.G.; Pinder, D.; Hundley, W.G.; Bluemke, D.A.; Kronmal, R.A.; Lima, J.A.C.; Kawut, S.M. Relationship of CRP, IL-6, and Fibrinogen with Right Ventricular Structure and Function: The MESA-Right Ventricle Study. Int. J. Cardiol. 2013, 168, 3818-3824. [CrossRef]

57. Quarck, R.; Nawrot, T.; Meyns, B.; Delcroix, M. C-reactive protein: A new predictor of adverse outcome in pulmonary arterial hypertension. J. Am. Coll. Cardiol. 2009, 53, 1211-1218. [CrossRef] [PubMed]

58. Abul, Y.; Karakurt, S.; Ozben, B.; Toprak, A.; Celikel, T. C-Reactive Protein in Acute Pulmonary Embolism. J. Investig. Med. 2011, 59, 8-14. [CrossRef]

59. Papageorgiou, N.; Tousoulis, D.; Androulakis, E.; Antoniades, C.; Tentolouris, C.; Stefanadis, C. Inflammation and right ventricle: The hunting of the missing link. Int. J. Cardiol. 2013, 168, 3152-3154. [CrossRef]

60. Omland, T.; Rosjo, H.; Giannitsis, E.; Agewall, S. Troponins in heart failure. Clin. Chim. Acta 2015, 443, 78-84. [CrossRef]

61. Kaczyńska, A.; Szulc, M.; Styczynski, G.; Kostrubiec, M.; Pacho, R.; Pruszczyk, P. Right ventricle injury during acute pulmonary embolism leads to its remodeling. Int. J. Cardiol. 2008, 125, 120-121. [CrossRef]

62. Kline, J.A.; Zeitouni, R.; Marchick, M.R.; Hernandez-Nino, J.; Rose, G.A. Comparison of 8 biomarkers for prediction of right ventricular hypokinesis 6 months after submassive pulmonary embolism. Am. Hear. J. 2008, 156, 308-314. [CrossRef]

63. Saunders, J.T.; Nambi, V.; de Lemos, J.A.; Chambless, L.E.; Virani, S.S.; Boerwinkle, E.; Hoogeveen, R.C.; Liu, X.; Astor, B.C.; Mosley, T.H.; et al. Cardiac Troponin T Measured by a Highly Sensitive Assay Predicts Coronary Heart Disease, Heart Failure, and Mortality in the Atherosclerosis Risk in Communities Study. Circulation 2011, 123, 1367-1376. [CrossRef]

64. Becattini, C.; Vedovati, M.C.; Agnelli, G. Prognostic value of troponins in acute pulmonary embolism: A meta-analysis. Circulation 2007, 116, 427-433. [CrossRef]

65. Parissis, J.T.; Ikonomidis, I.; Rafouli-Stergiou, P.; Mebazaa, A.; Delgado, J.; Farmakis, D.; Vilas-Boas, F.; Paraskevaidis, I.; Anastasiou-Nana, M.; Follath, F. Clinical Characteristics and Predictors of In-Hospital Mortality in Acute Heart Failure With Preserved Left Ventricular Ejection Fraction. Am. J. Cardiol. 2011, 107, 79-84. [CrossRef]

66. Daquarti, G.; Vecchio, N.M.; Mitrione, C.S.; Furmento, J.; Ametrano, M.C.; Pace, M.P.D.; Costabel, J.P.; Gustavo, D.; Nicolás, M.V.; Soledad, M.C.; et al. High-sensitivity troponin and right ventricular function in acute pulmonary embolism. Am. J. Emerg. Med. 2016, 34, 1579-1582. [CrossRef] 
67. Filusch, A.; Giannitsis, E.; Katus, H.A.; Meyer, FJ. High-sensitive troponin T: A novel biomarker for prognosis and disease severity in patients with pulmonary arterial hypertension. Clin. Sci. 2010, 119, $207-213$. [CrossRef]

68. Lai, C.T.M.; Wong, S.J.; Ip, J.J.K.; Wong, W.-K.; Tsang, K.-C.; Lam, W.W.M.; Cheung, Y.-F. Plasma Levels of High Sensitivity Cardiac Troponin T in Adults with Repaired Tetralogy of Fallot. Sci. Rep. 2015, 5, 14050. [CrossRef]

69. Omar, A.S.; Sudarsanan, S.; Hanoura, S.; Osman, H.; Sivadasan, P.C.; Shouman, Y.; Tuli, A.K.; Singh, R.; Al Khulaifi, A. Kinetics of Highly Sensitive Troponin T after Cardiac Surgery. BioMed Res. Int. 2015, 2015, 574546. [CrossRef]

70. Yan, A.T.; Liu, P.P. Narrative Review: Pharmacotherapy for Chronic Heart Failure: Evidence from Recent Clinical Trials. Ann. Intern. Med. 2005, 142, 132-145. [CrossRef]

71. Hogenhuis, J.; Voors, A.A.; Jaarsma, T.; Hoes, A.W.; Hillege, H.L.; Kragten, J.A.; Van Veldhuisen, D.J. Anaemia and renal dysfunction are independently associated with BNP and NT-proBNP levels in patients with heart failure. Eur. J. Hear. Fail. 2007, 9, 787-794. [CrossRef]

72. Mukoyama, M.; Nakao, K.; Hosoda, K.; Suga, S.; Saito, Y.; Ogawa, Y.; Shirakami, G.; Jougasaki, M.; Obata, K.; Yasue, H. Brain natriuretic peptide as a novel cardiac hormone in humans. Evidence for an exquisite dual natriuretic peptide system, atrial natriuretic peptide and brain natriuretic peptide. J. Clin. Investig. 1991, 87, 1402-1412. [CrossRef]

73. Levin, E.R.; Gardner, D.G.; Samson, W.K. Natriuretic peptides. N. Engl. J. Med. 1998, 339, 321-328.

74. Hunt, P.J.; Doughty, R.N.; Richards, A.M.; Nicholls, M.G.; Yandle, T.G.; Espiner, E.A. Immunoreactive amino-terminal pro-brain natriuretic peptide (NT-PROBNP): a new marker of cardiac impairment. Clin. Endocrinol. 1997, 47, 287-296. [CrossRef]

75. Maisel, A.S.; Krishnaswamy, P.; Nowak, R.M.; McCord, J.; Hollander, J.E.; Duc, P.; Omland, T.; Storrow, A.B.; Abraham, W.T.; Wu, A.H.; et al. Rapid measurement of B-type natriuretic peptide in the emergency diagnosis of heart failure. N. Engl. J. Med. 2002, 347, 161-167. [CrossRef]

76. Leuchte, H.H.; El Nounou, M.; Tuerpe, J.C.; Hartmann, B.; Baumgartner, R.A.; Vogeser, M.; Muehling, O.; Behr, J. N-terminal Pro-Brain Natriuretic Peptide and Renal Insufficiency as Predictors of Mortality in Pulmonary Hypertension. Chest 2007, 131, 402-409. [CrossRef]

77. Ganem, F.; Serrano, C.V.; Fernandes, J.L.; Blotta, M.H.S.; Souza, J.A.; Nicolau, J.C.; Ramires, J.A.; Hueb, W.A. Preoperative B-type natriuretic peptide, and not the inflammation status, predicts an adverse outcome for patients undergoing heart surgery. Interact. Cardiovasc. Thorac. Surg. 2011, 12, 778-783. [CrossRef] [PubMed]

78. Cuthbertson, B.; Croal, B.; Rae, D.; Gibson, P.; McNeilly, J.; Jeffrey, R.; Smith, W.C.; Prescott, G.; Buchan, K.; El-Shafei, H.; et al. N-terminal pro-B-type natriuretic peptide levels and early outcome after cardiac surgery: a prospective cohort study. Br. J. Anaesth. 2009, 103, 647-653. [CrossRef] [PubMed]

79. Fellahi, J.-L.; Daccache, G.; Rubes, D.; Massetti, M.; Gérard, J.-L.; Hanouz, J.-L. Does Preoperative B-Type Natriuretic Peptide Better Predict Adverse Outcome and Prolonged Length of Stay Than the Standard European System for Cardiac Operative Risk Evaluation After Cardiac Surgery? J. Cardiothorac. Vasc. Anesthesia 2011, 25, 256-262. [CrossRef]

80. Holm, J.; Vidlund, M.; Vanky, F.; Friberg, Ö.; Håkanson, E.; Walther, S.; Svedjeholm, R. EuroSCORE II and $\mathrm{N}$-terminal pro-B-type natriuretic peptide for risk evaluation: an observational longitudinal study in patients undergoing coronary artery bypass graft surgery. Br. J. Anaesth. 2014, 113, 75-82. [CrossRef] [PubMed]

81. Di Salvo, T.G.; Mathier, M.; Semigran, M.J.; Dec, G.W. Preserved right ventricular ejection fraction predicts exercise capacity and survival in advanced heart failure. J. Am. Cardiol. 1995, 25, 1143-1153. [CrossRef]

82. Zornoff, L.A.; Skali, H.; Pfeffer, M.A.; Sutton, M.S.J.; Rouleau, J.L.; Lamas, G.A.; Plappert, T.; Rouleau, J.R.; Moye, L.A.; Lewis, S.J.; et al. Right ventricular dysfunction and risk of heart failure and mortality after myocardial infarction. J. Am. Cardiol. 2002, 39, 1450-1455. [CrossRef]

83. Kruger, S.; Graf, J.; Merx, M.W.; Koch, K.C.; Kunz, D.; Hanrath, P.; Janssens, U. Brain natriuretic peptide predicts right heart failure in patients with acute pulmonary embolism. Am. Heart J. 2004, 147, 60-65. [CrossRef]

84. Klok, F.A.; Van Der Bijl, N.; Eikenboom, H.C.J.; Van Rooden, C.J.; De Roos, A.; Kroft, L.J.M.; Huisman, M.V. Comparison of $\mathrm{CT}$ assessed right ventricular size and cardiac biomarkers for predicting short-term clinical outcome in normotensive patients suspected of having acute pulmonary embolism. J. Thromb. Haemost. 2010, 8, 853-856. [CrossRef] 
85. Blyth, K.G.; Groenning, B.A.; Mark, P.B.; Martin, T.N.; Foster, J.E.; Steedman, T.; Morton, J.J.; Dargie, H.J.; Peacock, A.J.; Mark, P. NT-proBNP can be used to detect right ventricular systolic dysfunction in pulmonary hypertension. Eur. Respir. J. 2007, 29, 737-744. [CrossRef]

86. Nagaya, N.; Nishikimi, T.; Okano, Y.; Uematsu, M.; Satoh, T.; Kyotani, S.; Kuribayashi, S.; Hamada, S.; Kakishita, M.; Nakanishi, N.; et al. Plasma Brain Natriuretic Peptide Levels Increase in Proportion to the Extent of Right Ventricular Dysfunction in Pulmonary Hypertension. J. Am. Cardiol. 1998, 31, 202-208. [CrossRef]

87. Clerico, A.; Iervasi, G.; Pilo, A. Turnover Studies on Cardiac Natriuretic Peptides: Methodological, Pathophysiological and Therapeutical Considerations. Curr. Drug Metab. 2000, 1, 85-105. [CrossRef]

88. Hara, H.; Ogihara, T.; Shima, J.; Saito, H.; Rakugi, H.; Iinuma, K.; Kumahara, Y.; Minamino, T. Plasma Atrial Natriuretic Peptide Level As an Index for the Severity of Congestive Heart Failure. Clin. Cardiol. 1987, 10, 437-442. [CrossRef]

89. Nagaya, N.; Nishikimi, T.; Uematsu, M.; Satoh, T.; Kyotani, S.; Sakamaki, F.; Kakishita, M.; Fukushima, K.; Okano, Y.; Nakanishi, N.; et al. Plasma Brain Natriuretic Peptide as a Prognostic Indicator in Patients With Primary Pulmonary Hypertension. Circulation 2000, 102, 865-870. [CrossRef]

90. Gutte, H.; Mortensen, J.; Jensen, C.V.; Von Der Recke, P.; Petersen, C.L.; Kristoffersen, U.S.; Kjaer, A. ANP, BNP and D-dimer predict right ventricular dysfunction in patients with acute pulmonary embolism. Clin. Physiol. Funct. Imaging 2010, 30, 466-472. [CrossRef]

91. Groenning, B.A.; Nilsson, J.C.; Sondergaard, L.; Kjaer, A.; Larsson, H.B.; Hildebrandt, P.R. Evaluation of impaired left ventricular ejection fraction and increased dimensions by multiple neurohumoral plasma concentrations. Eur. J. Hear. Fail. 2001, 3, 699-708. [CrossRef]

92. Weir, R.A.; Petrie, C.J.; Murphy, C.A.; Clements, S.; Steedman, T.; Miller, A.M.; McInnes, I.B.; Squire, I.B.; Ng, L.L.; Dargie, H.J.; et al. Galectin-3 and Cardiac Function in Survivors of Acute Myocardial Infarction. Circ. Hear. Fail. 2013, 6, 492-498. [CrossRef]

93. Milting, H.; Kramer, F.; Ellinghaus, P.; Çakar, H.; Bohms, B.; Kassner, A.; Kastning, H.; Lauenroth, V.; Krahn, T.; Kruska, L.; et al. 376: Novel Plasma Biomarkers of Myocardial Fibrosis and Remodeling in Terminal Heart Failure Patients Supported by Mechanical Circulatory Support Devices. J. Hear. Lung Transplant. 2008, 27, S196-S197. [CrossRef]

94. Diagnostics, C. Aspect-LFTM ST2 Test. Available online: http://www.criticaldiagnostics.com/OUS/products/ aspect.htm (accessed on 1 January 2019).

(C) 2019 by the authors. Licensee MDPI, Basel, Switzerland. This article is an open access article distributed under the terms and conditions of the Creative Commons Attribution (CC BY) license (http://creativecommons.org/licenses/by/4.0/). 